\title{
Composition of essential oil and fatty acids of Centaurea pichleri ssp. pichleri
}

\section{Pelin TAŞTAN *1, Tuğçe FAFAL ${ }^{1}$, Burcu SÜMER TÜZÜN¹, Tuba GÖNENÇ¹, Betül DEMİRC İ ${ }^{2}$ Bijen KIVÇAK ${ }^{1}$}

${ }^{1}$ Ege University, Faculty of Pharmacy Pharmacognosy Department, Izmir, Turkey

${ }^{2}$ Anadolu University, Faculty of Pharmacy Pharmacognosy Department, Eskişehir, Turkey

Received: 29 April 2017 - Revised: Accepted: 03 June 2017

\begin{abstract}
In this study, the essential oil of Centaurea pichleri ssp. pichleri was obtained by hydrodistillation using a Clevenger-type apparatus. GC and GC/MS analyzes of the essential oil from Centaurea pichleri ssp. pichleri were determined the identification of 48 components representing $86.9 \%$ of the oil. With this analysis, the major component was found as hexadecanoic acid (31.4\%). Subsequent to this component, other major components were caryophyllene oxide (6.4\%), spathulenol (6.2\%) and dodecanoic acid (4.5\%). In addition to this, fatty acid methyl esters (FAMEs) from Centaurea pichleri ssp. pichleri were prepared for analyzes of fatty acids. By this test the amount of saturated fatty acid (SFA) was found as $47.79 \%$ with major fatty acid was stearic acid (18.64\%). The amount of monounsaturated fatty acid (MUFA) was found as $16.88 \%$ with major fatty acid was oleic acid $(14.20 \%)$. The amount of polyunsaturated fatty acid (PUFA) was found as $21.29 \%$ with major fatty acid was linoleic acid (15.20\%). The results from this work were compared with the previous works in terms of essential oils and fatty acids.
\end{abstract}

Keywords: Centaurea pichleri ssp. pichleri; essential oil; GC; GC/MS; fatty acid

\section{INTRODUCTION}

In Asteraceae family, Centaurea genus is one of the largest genus according to having species. Centaurea genus is represented with 192 taxa in Turkey, 114 of which are endemic [1]. Many species of the genus Centaurea have traditionally been used for their antirheumatic, diuretic, choleretic, stomachic, astringent, cytotoxic, antibacterial, antipyretic and tonic properties [2,3]. The essential oil compositions of some Centaurea species from Turkey have been investigated. Generally, germacrene D, hexadecanoic acid, caryophyllene and caryophyllene oxide were reported to be the major volatile components in the earlier studies. In Centaurea genus, Centaurea pichleri ssp. pichleri is known as "gelin düğmesi, peygamber çiçeği” in Turkey.

Fatty acid, either saturated or unsaturated, is a carboxylic acid with a long aliphatic chain. Most naturally occurring fatty acids have an even numbered chain of carbon atoms ranging from 4 to 28. Fatty acids that have carbon-carbon double bonds are known as unsaturated fatty

\footnotetext{
*Corresponding Author E-mail: pelintastan35@gmail.com
} 
acids whereas acids without double bonds are known as saturated fatty acids. They differ in chain length as well.

To our knowledge, there are no previous studies on the essential oil and fatty acids of Centaurea pichleri ssp. pichleri. The analysis of essential oil of some plants from Centaurea genus have previously been reported [4-10].

\section{MATERIAL and METHODS}

\subsection{Plant Material and Isolation of Essential Oil}

The plant Centaurea pichleri ssp. pichleri was collected on 12 June 2011 at an altitude of $1450 \mathrm{~m}$ in Elazığg, Turkey. The plant was identified by Ugur Cakilcioglu (Elazığ Directorate of National Education, Elazığ, Turkey). Voucher speciments of the plant are deposited in Faculty of Pharmacy, Ege University with the number 1470. For obtaining the essential oil of Centaurea pichleri ssp. pichleri was done by using the method 'hydrodistillation'. For this, the air dried aerial parts of the plant was subjected to distillation by Clevenger apparatus for $3 \mathrm{~h}$. After that the essential oil of the plant was obtained. This essential oil was stored at $+4{ }^{\circ} \mathrm{C}$ until using.

\subsection{Oil Extraction and Preparation of Fatty Acid Methyl Esters (FAMEs)}

For the analysis of fatty acid of Centaurea pichleri ssp. pichleri, air-dried and powdered aerial parts of the plant was extracted at $60^{\circ} \mathrm{C}$ by Soxhlet extractor, using petroleum ether as a solvent. After oil extraction the solvent was removed by a rotary evaporator.

The extracted oil was esterified to determine the fatty acid composition. The fatty acids in the total lipid were esterified into methyl esters by saponification with $0.5 \mathrm{~N}$ methanolic $\mathrm{NaOH}$ and transesterified with $14 \% \mathrm{BF}$ (v/v) in methanol [11].

\subsection{Gas Chromatography (GC)}

Gas chromatography analysis was carried out with an Agilent 6890 N GC system. Temperature of FID detector was $300{ }^{\circ} \mathrm{C}$. Simultaneous autoinjection was done on a duplicate of the same column applying the same operational conditions to obtain the same elution order with GC-MS. The relative percentage amounts of the separated compounds were calculated from FID chromatograms.

Fatty acid methyl esters (FAMEs) were analyzed on a HP (Hewlett Packard) Agilent 6890 $\mathrm{N}$ model gas chromatograph (GC), equipped with a flame ionization detector (FID) and fitted to a Supelco SP-2380 Fased Silica capillary column ( $60 \mathrm{~m}, 0.25 \mathrm{~mm}$ i.d. and $0.2 \mu \mathrm{m})$. Injector and detector temperatures were set at $250{ }^{\circ} \mathrm{C}$ and $260{ }^{\circ} \mathrm{C}$, respectively. The oven was programmed at $140{ }^{\circ} \mathrm{C}$ for initial temperature and $5 \mathrm{~min}$ for initial time. Thereafter the temperature was increased up to $240^{\circ} \mathrm{C}$ at a rate of $3^{\circ} \mathrm{C} / \mathrm{min}$. The total run time was $41.33 \mathrm{~min}$. For the carrier gas helium was used $(1 \mathrm{ml} / \mathrm{min})$. Identification of fatty acids was carried out by comparing sample FAME peak relative retention times. The results were expressed as FID response area in the relative percentages. Each reported result was given as the average value of three GC analyzes. The results are offered as means \pm S.D.

\subsection{Gas Chromatography / Mass Spectrometry (GC / MS)}

The GC/MS analysis were carried out with an Agilent 5975 GC-MSD system. Innowax FSC column $(60 \mathrm{~m} \times 0.25 \mathrm{~mm}, 0.25 \mathrm{~mm}$ film thickness $)$ was used with helium as carrier gas $(0.8 \mathrm{~mL} / \mathrm{min})$. GC oven temperature was kept at $60^{\circ} \mathrm{C}$ for $10 \mathrm{~min}$ and programmed to $220^{\circ} \mathrm{C}$ at a rate of $4{ }^{\circ} \mathrm{C} / \mathrm{min}$ and kept constant at $220^{\circ} \mathrm{C}$ for $10 \mathrm{~min}$ and then programmed to $240{ }^{\circ} \mathrm{C}$ at a rate of $1{ }^{\circ} \mathrm{C} / \mathrm{min}$. Split ratio was adjusted at $40: 1$. The injector temperature was set at $250{ }^{\circ} \mathrm{C}$. Mass spectra were recorded at $70 \mathrm{eV}$. Mass range was from m/z 35 to 450 . 
The essential oil components were identified by comparison of Mass spectra with those in Wiley GC/MS Library, Adams Library, MassFinder Library and in Baser Library of Essential Oil Constituents which was built up by genuine compounds and components of known oils. Identification of the essential oil components were carried out by comparison of their relative retention times and their relative retention indices (RRI). The results of analysis are given in Table 1.

\section{RESULTS and DISCUSSIONS}

Composition of the essential oil of Centaurea pichleri ssp. pichleri is listed in Table 1 with relative retantion rates (RRI) and percentages. With this analysis 48 components were identified in the essential oil of the plant. These components were represented $86.9 \%$ of the oil. Fatty acid composition of Centaurea pichleri ssp. pichleri is listed in Table 2.

Table 1. Composition of the essential oil of Centaurea pichleri ssp. pichleri

\begin{tabular}{|c|c|c|}
\hline RRI & Component & Percentage \\
\hline 1360 & 1-Hexanol & 0.3 \\
\hline 1391 & (Z)-3-Hexenol & 1.2 \\
\hline 1400 & Nonanal & 0.3 \\
\hline 1452 & 1-Octen-3-ol & 0.5 \\
\hline 1553 & Linalool & 0.7 \\
\hline 1612 & $\beta$-Caryophyllene & 1.0 \\
\hline 1664 & Nonanol & 0.8 \\
\hline 1668 & $(Z)-\beta$-Farnesene & 0.7 \\
\hline 1706 & $\alpha$-Terpineol & 0.4 \\
\hline 1726 & Germacrene D & 1.8 \\
\hline 1741 & $\beta$-Bisabolene & 0.8 \\
\hline 1766 & Decanol & 0.4 \\
\hline 1773 & $\delta$-Cadinene & 0.4 \\
\hline 1838 & (E)- $\beta$-Damascenone & 0.4 \\
\hline 1868 & (E)-Geranyl acetone & 0.3 \\
\hline 1871 & 1-Undecanol & 0.1 \\
\hline 1941 & $\alpha$-Calacorene & 0.6 \\
\hline 1945 & 1,5-Epoxy-salvial(4)14-ene & 1.5 \\
\hline 1958 & (E)- $\beta$-Ionone & 1.4 \\
\hline 1973 & Dodecanol & 0.3 \\
\hline 2008 & Caryophyllene oxide & 6.4 \\
\hline 2037 & Salvial-4(14)-en-1-one & 0.6 \\
\hline 2071 & Humulene epoxide-II & 1.1 \\
\hline 2080 & Junenol (=Eudesm-4(15)-en-6-ol) & 0.5 \\
\hline 2098 & Globulol & 0.5 \\
\hline 2130 & Salviadienol & 0.5 \\
\hline 2131 & Hexahydrofarnesyl acetone & 1.2 \\
\hline 2144 & Spathulenol & 6.2 \\
\hline 2179 & 3,4-Dimethyl-5-pentylidene-2(5H)-furanone & 0.6 \\
\hline 2187 & T-Cadinol & 0.5 \\
\hline 2192 & Nonanoic acid & 0.9 \\
\hline 2209 & T-Muurolol & 0.6 \\
\hline 2247 & Trans- $\alpha$-Bergamotol & 0.3 \\
\hline 2255 & $\alpha$-Cadinol & 1.4 \\
\hline 2278 & Torilenol & 0.8 \\
\hline 2298 & Decanoic acid & 0.7 \\
\hline 2324 & $\begin{array}{c}\text { Caryophylla-2(12),6(13)-dien-5a-ol } \\
\text { (=Caryophylladienol II) }\end{array}$ & 1.0 \\
\hline
\end{tabular}




\begin{tabular}{|c|c|c|}
\hline 2369 & 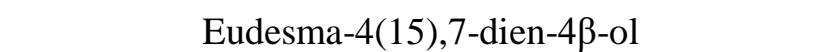 & 1.3 \\
\hline 2389 & Caryophylla-2(12),6-dien-5a-ol (=Caryophyllenol I) & 1.4 \\
\hline 2392 & Caryophylla-2(12),6-dien-5ß-ol (=Caryophyllenol II) & 1.3 \\
\hline 2500 & Pentacosane & 0.5 \\
\hline 2503 & Dodecanoic acid & 4.5 \\
\hline 2509 & Methyl linoleate & 0.8 \\
\hline 2622 & Phytol & 3.0 \\
\hline 2670 & Tetradecanoic acid & 2.7 \\
\hline 2700 & Heptacosane & 1.5 \\
\hline 2822 & Pentadecanoic acid & 0.8 \\
\hline \multirow[t]{2}{*}{2931} & Hexadecanoic acid & 31.4 \\
\hline & TOTAL & 86.9 \\
\hline
\end{tabular}

Table 2. Fatty acid composition of Centaurea pichleri ssp. pichleri

\begin{tabular}{lc}
\hline Fatty acids & Centaurea pichleri ssp. pichleri \\
\hline C 6:0 (Caproic acid) & $2.09^{\mathrm{a}}$ \\
C 8:0 (Caprylic acid) & 5.22 \\
C 14:0 (Myristic acid) & 3.09 \\
C 15:0 (Pentadecanoic acid) & 1.18 \\
C 16:0 (Palmitic acid) & 9.28 \\
C 17:0 (Heptadecanoic acid) & 2.01 \\
C 18:0 (Stearic acid) & 18.64 \\
C 21:0 (Heneicosanoic acid) & 4.20 \\
C 22:0 (Behenic acid) & 2.08 \\
¿SFA & 47.79 \\
C 18:1 $\omega 9$ (Oleic acid) & 14.20 \\
C 20:1 $\omega 9$ (Gondoic acid) & 2.68 \\
¿MUFA & 16.88 \\
C 18:2 $\omega 6$ (Linoleic acid) & 15.20 \\
C 18:3 $\omega 6$ ( $\gamma$-linolenic acid) & 6.09 \\
¿ PUFA & 21.29
\end{tabular}

${ }^{a}$ Values reported are means \pm SD of 3 lots analysed.

${ }^{\mathrm{b}}$ SFA: Saturated fatty acids, MUFA: Monounsaturated fatty acids, PUFA: Polyunsaturated fatty acids.

\section{DISCUSSION}

From the analysis of essential oil of the plant, it is seen that hexadecanoic acid is the major acid. Hexadecanoic acid was previously found as the major component of essential oils of Centaurea aladagensis, C. luschaiana, C. tossiensis, Centaurea aggregata subsp. aggregata, C. balsamita, $C$. behen, $C$. wagenitzii, $C$. iberica, $C$. hyalolepis and $C$. polyclada from Turkey $[9,10,12,13]$. Hexadecanoic acid, the most common saturated fatty acid which is found in animals, plants and microorganisms was known to raise plasma cholesterol concentrations and also dietary intakes of saturated fatty acids were shown to increase the possibility of coronary heart diseases [14].

With the fatty acid analysis, totally 13 fatty acids were identified in the oil of the plant. For the saturated fatty acids, the major acid was stearic acid as $18.64 \%$. For the monounsaturated fatty acids the major acid was oleic acid as $14.20 \%$. for polyunsaturated fatty acids the major acid was linoleic acid as $15.20 \%$. Saturated fatty acids amounted to $47.79 \%$ of the total fatty acids, while the unsaturated fatty acids were $38.17 \%$. There have been previous 
studies on fatty acids of some Centaurea species $[5,15]$. When these results are compared with the previous studies, our results are shown meaningful.

Linoleic acid, for the major polyunsaturated acid, is necessary in adequate amounts for health. Lack of dietary essential fatty acids such as linoleic acid has been implicated in aetiology of diseases including cardiovascular disease and its progression [16]. And also oleic acid, the major monounsaturated fatty acid for the plant, has the capability to lower blood cholesterol levels like linoleic acid. Intake of these fatty acids (oleic and linoleic acids) are promoted by nutritionists and the health professionals [17]. Oleic acid, with the ability of reducing lowdensity lipoprotein (LDL) levels and possibly increasing high-density lipoprotein (HDL) levels, is known as a monounsaturated fatty acid in normal diet $[16,18]$.

In conclusion, this is the first report on the essential oil and fatty acid composition of Centaurea pichleri ssp. pichleri.

\section{Conflict of Interests}

Authors declare that there is no conflict of interests.

\section{REFERENCES}

[1]. Davis, P. H., \& Davis P. (1975). Flora of Turkey and the East Aegean Islands. Vol. 5. Edinburgh.

[2]. Baytop, T. (1999). Türkiye'de Bitkiler ile Tedavi. İstanbul: Nobel Tıp Kitabevleri.

[3]. Dalar, A., \& Konczak, I. (2012). Botanicals from Eastern Anatolia Region of Turkey: Antioxidant capacity and phenolic constituents of endemic herbal medicines. Journal of Herbal Medicine, 2(4), 126-135. https://doi.org/10.1016/j.hermed.2012.08.001

[4]. Ertuğrul, K., Dural, H., Bağcı, Y., Demirelma, H., Flamini, G., Cioni, P. ., \& Morelli, I. (2003). Essential Oil Composition of Two Endemic Centaurea Species From Turkey Centaurea Mucronifera and Centaurea Chrysantha Collected in The Same Habitat. BIOCHEMICAL SYSTEMATICS AND ECOLOGY.

[5]. Erdogan, T., Gonenc, T., Cakilcioglu, U., \& Kivcak, B. (2014). Fatty Acid Composition of the Aerial Parts of Some Centaurea Species in Elazig, Turkey. Tropical Journal of Pharmaceutical Research, 13(4), 613. https://doi.org/10.4314/tjpr.v13i4.19

[6]. Başer, K. H. C., Özek, G., Özek, T., \& Duran, A. (2006). Composition of the essential oil of Centaurea huber-morathii Wagenitz isolated from seeds by microdistillation, 21(3), 568-570. https://doi.org/10.1002/ffj.1620

[7]. Polatoglu, K., Sen, A., Bulut, G., Bitis, L., \& Gören, N. (2014). Essential Oil Composition of Centaurea stenolepis Kerner. from Turkey. Journal of Essential Oil Bearing Plants, 17(6), 1268-1278. https://doi.org/10.1080/0972060X.2014.935090

[8]. Karamenderes, C., Demirci, B., \& Baser, K. H. C. (2008). Composition of Essential Oils of Ten Centaurea L. Taxa from Turkey. Journal of Essential Oil Research, 20(4), 342349. https://doi.org/10.1080/10412905.2008.9700027

[9]. Bülent Köse, Y., İşcan, G., Demirci, B., Başer, K. H. C., \& Çelik, S. (2007). Antimicrobial activity of the essential oil of Centaurea aladagensis. Fitoterapia, 78(3), 253-254. https://doi.org/10.1016/j.fitote.2006.12.002

[10]. Köse, Y. B., Demirci, B., Başer, K. H. C., \& Yücel, E. (2008). Composition of the Essential Oil of Three Endemic Centaurea Species From Turkey. Journal of Essential Oil Research, 20(4), 335-338. https://doi.org/10.1080/10412905.2008.9700025

[11]. Amin, Gh, Salehi, MH, Yasa, N. (2002). Screening of Iranian plants for antifungal activity: Part 2. DARU Journal of Pharmaceutical Sciences, 10(2), 78-89. 
[12]. Erel, S. B., Demirci, B., Demir, S., Karaalp, C., \& Hüsnü Can Baser, K. (2013). Composition of the essential oils of Centaurea aphrodisea, C. polyclada, C. athoa, C. hyalolepis and C. iberica. Journal of Essential Oil Research, 25(2), 79-84. https://doi.org/10.1080/10412905.2012.755476

[13]. Erdoğan, T., Sümer, B., Özçınar, Ö., Çakılcığlu, U., Demirci, B., Başer, K. H. C., \& Kivçak, B. (2017). Essential Oil Composition of Three Centaurea Species from Turkey: Centaurea aggregata Fisch. \&amp; Mey. ex. DC.subsp. aggregata, C. balsamita Lam. and C. behen L. Records of Natural Products, 11(1), 69-73.

[14]. Connor, W. E. (1999). Harbingers of coronary heart disease: dietary saturated fatty acids and cholesterol. Is chocolate benign because of its stearic acid content? The American Journal of Clinical Nutrition, 70(6), 951-2.

[15] Tekeli, Y., Sezgin, M., Aktumsek, A., Ozmen Guler, G., \& Aydin Sanda, M. (2010). Fatty acid composition of six Centaurea species growing in Konya, Turkey. Natural Product Research, 24(20), 1883-1889. https://doi.org/10.1080/14786411003754314

[16]. Parikh, P., McDaniel, M. C., Ashen, M. D., Miller, J. I., Sorrentino, M., Chan, V., ... Sperling, L. S. (2005). Diets and Cardiovascular Disease : an evidence-based assessment. Journal of the American College of Cardiology, 45(9), 1379-1387. https://doi.org/10.1016/j.jacc.2004.11.068

[17]. Johnson, G. H., \& Fritsche, K. (2012). Effect of Dietary Linoleic Acid on Markers of Inflammation in Healthy Persons: A Systematic Review of Randomized Controlled Trials. Journal of the Academy of Nutrition and Dietetics, 112(7), 1029-1041.e15. https://doi.org/10.1016/j.jand.2012.03.029

[18]. Swanson, D., Block, R., \& Mousa, S. A. (2012). Omega-3 Fatty Acids EPA and DHA: Health Benefits Throughout Life. Advances in Nutrition: An International Review Journal, 3(1), 1-7. https://doi.org/10.3945/an.111.000893 